\title{
THE HAGUE, KONINKLIJKE BIBLIOTHEEK (KB, ROYAL LIBRARY)
}

\section{Address: Prins Willem-Alexanderhof 5}

The Royal Library had its origin in the collection of the two last Stadtholders of the Dutch Republic, Willem IV and Willem V. The latter fled to England in 1795 , and three years later, in 1798 , the Parliament of the newly founded Batavian Republic decided to turn the collection, comprising about 5000 books and manuscripts, into a National Library. In 1806, during the reign of the French King Louis Napoleon, the term 'National' was changed to 'Royal'. Since then the holdings have expanded continually, and at present the collection boasts about 2.2 million volumes.

The library's acquisition policy does not encompass materials of nonWestern origin, and in the 19th century some Oriental manuscripts in its possession were transferred to the Leiden University Library (see Vol. II, Chapter 10). Nevertheless, the rich manuscript collection does contain some Oriental items besides texts in Western languages which have a documentary value for the history of the Ottoman Empire. Apart from travelogues, these include interesting items such as a survey in Dutch of the salaries paid by the Ottoman Sultan to his officials, early 18 th century (Hs. $71 \mathrm{~J} 38,20 \mathrm{ff}$.), entitled De beschrijvinge vande salarissen, soldien, en vande incoemen, die den Turcxschen keijser geeft aen sijne slaven soo vande Militie ende aen allen anderen officieren, die in sijn dienst sijn; the MS had originally been bought for Prince Willem IV in 1749, cf. A.D. Renting \& J.T.C. Renting-Kuijpers, The Seventeenth-Century Orange-Nassau Library, Uterecht 1993, No. 2145; a Mémoire sur les turcs by François Emmanuel Guignard, comte de St. Priest, French envoy to the Porte, late 18th century (Hs. 129 B 9, 20 pp.); and a typescript journal in Dutch of a mission to Istanbul in 1915 by C.L. Torley Duwel (Hs. $134 \mathrm{C}_{15}, 34 \mathrm{pp}$, donated to the library by the author in 1952; see for details, Schmidt, Legation Window, pp. 36-41).

Some Oriental texts, mostly in Hebrew, and brief aphorisms or other quotations in, mostly, Arabic by scholars and students, are found in scrapbooks with dedications, sometimes illustrated or illuminated, by friends and acquaintances of the owners (album amicorum) - the genre was particularly popular in the $17^{\text {th }}$ and 18th century - a large collection of which is 


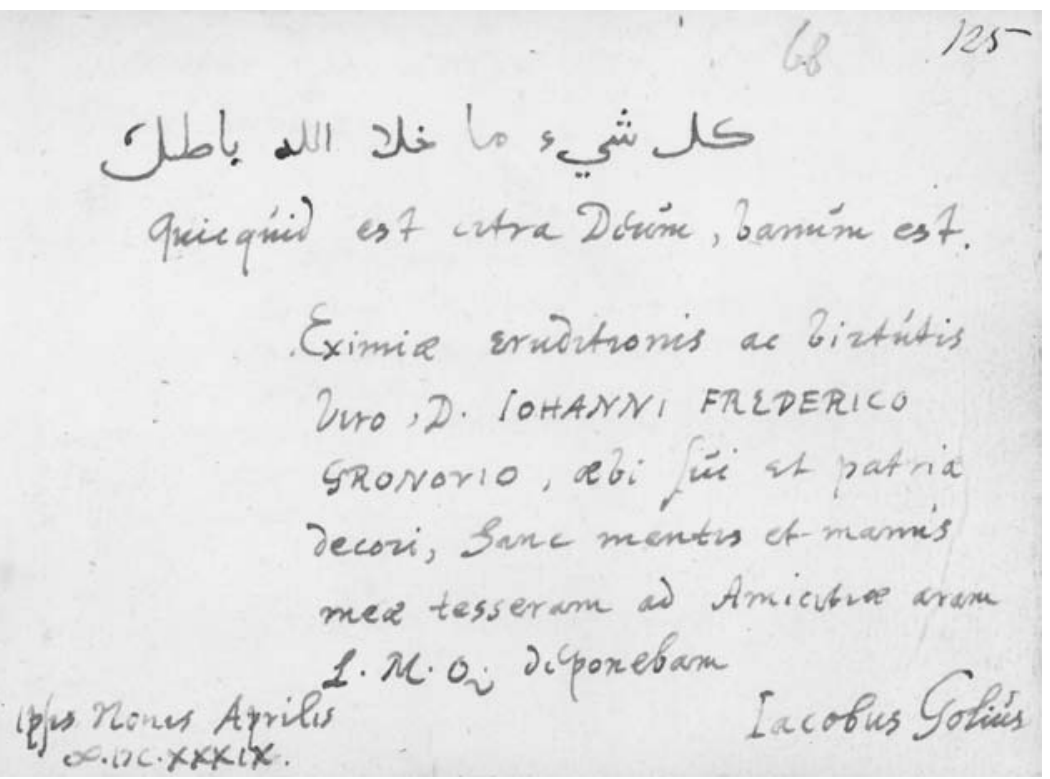

Figure 26. The Hague, KB Hs. 130 E 32, f. 68a. Inscription by the Leiden orientalist, Jacob Golius, dated 1639, in an album amicorum compiled by the classicist Gronovius (1611-1671).

being preserved in the library (and still being expanded). Only one item, Ms. $135 \mathrm{~K} 4$, separately described below, contains Turkish texts. Some of the Dutch alba in the collection contain inscriptions with Arabic phrases by Orientalists already encountered on these pages: Jacob Golius (twice: at Leiden, 1639, in Hs. 130 E 32, f. 68a, album compiled by the classicist, Johannes Fredericus Gronovius, 1611-1671, and at Leiden, 1644, in Hs. 129 F 6, f. 138a, album compiled by Johan Philip Mulhausen or Mulheuser, an officer serving in Brasil and the Dutch Republic) and Jan Jacob Schultens (at Leiden, 1766, in Hs. $133 \mathrm{H} \mathrm{28}$, f. 93a, album compiled by the Leiden philologist Laurentius van Santen, $1746-1798)$. There is one album compiled by an Orientalist, Joannes Willmet (1750-1835; see for his manuscripts, Leiden, UB, Academy of Arts and Sciences, below): Hs. $134 \mathrm{C} 44$, acquired from the antiquarian bookshop of Nijhoff in The Hague in 1956. It contains contributions by, among others, his colleagues Hendrik Albert Schultens (at Leiden, 1773, p. 145) and Hendrik Arent Hamaker (at Leiden, 1820, p. 215), and, curiously, by the famous Dutch poet and amateur-Orientalist, Willem Bilderdijk (1756-1831), who contributed, apart from a distich of Haăfiz in Persian, the lines En, moet de val der taal ons beider zang vernielen/ Uw uitspraak en uw naam verduren lot en tijds (at Amsterdam, 8 Oogstmaand 1812, p. 188). 


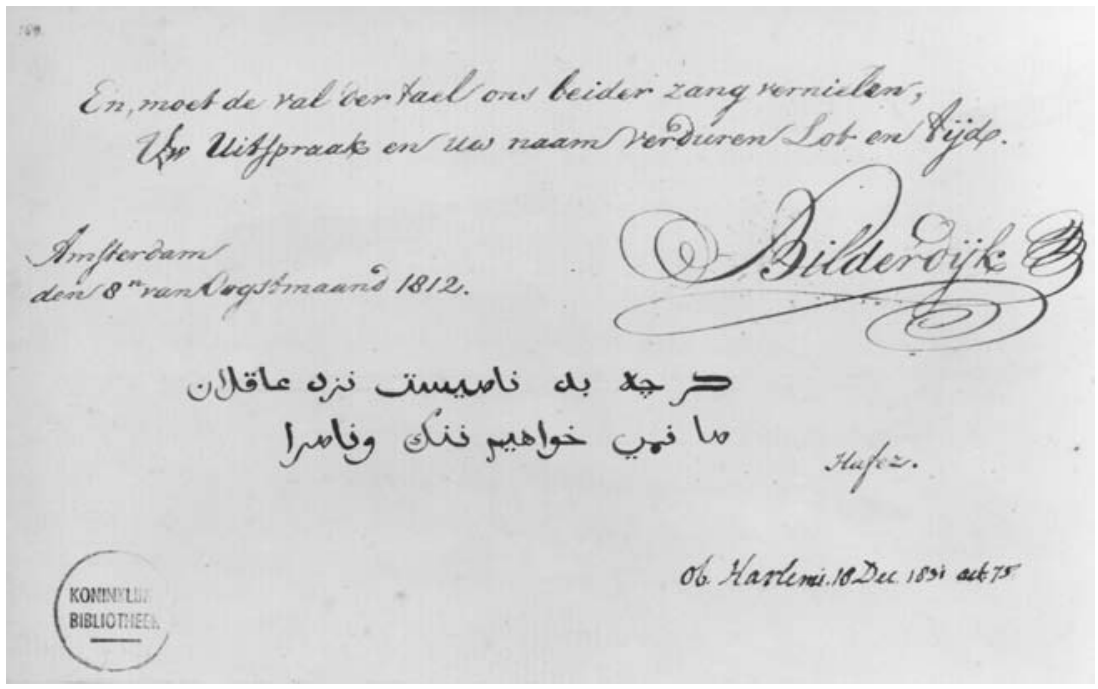

Figure 27. The Hague, KB Hs. 134 C 44, p. 188. Inscription, with a quotation of a verse by Hāfiz, made by the poet, Willem Bilderdijk, in an album amicorum compiled by the Dutch orientalist, Joannes Willmet (1750-1835).

Literature: Verzamelaars en verzamelingen. Koninklijke Bibliotheek $1798-1998$ (Zwolle 1998); K. Thomassen, ed., Alba Amicorum. Vijf eeuwen vriendschap op papier gezet: Het Album Amicorum en de poëziealbum in de Nederlanden (The Hague 1990).

\section{Hs. $135 \mathrm{~K} 4$}

\section{Turkish text fragments}

A second volume (out of three) of an album amicorum compiled by Ernst Brinck (c. 1582-1649), secretary to the first Dutch ambassador at the Porte, Cornelis Haga, between 1612 and 1615. It contains about 180 contributions in more than 200 languages during the years $1612-1635$, among them by Ottomans and Istanbul ambassadors; 188 folios, $155 \times 105 \mathrm{~mm}$. Three poems in Arabic and Persian by Bahā̄̄î, Jāmī and 'Urfì, and copied in calligraphic ta līk by the cubicularis of the Sultan, Aḥmed, also known as Tịrmānī (probably the mirāhnōr, Aḥmed Agia, in function 1020/1611-1023/1614, cf. $S O^{2} \mathrm{VI}$, p. 1736), are found on ff. gb-10a (see also the plate in Zeki Çelikkol, Alexander de Groot \& Ben J. Slot, "... It began with the tulip". The History of Four Centuries of Relationship between Turkey and the Netherlands in Pictures (Ankara 2000), p. 34). The volume had belonged to the Orientalist Joannes Willmet 


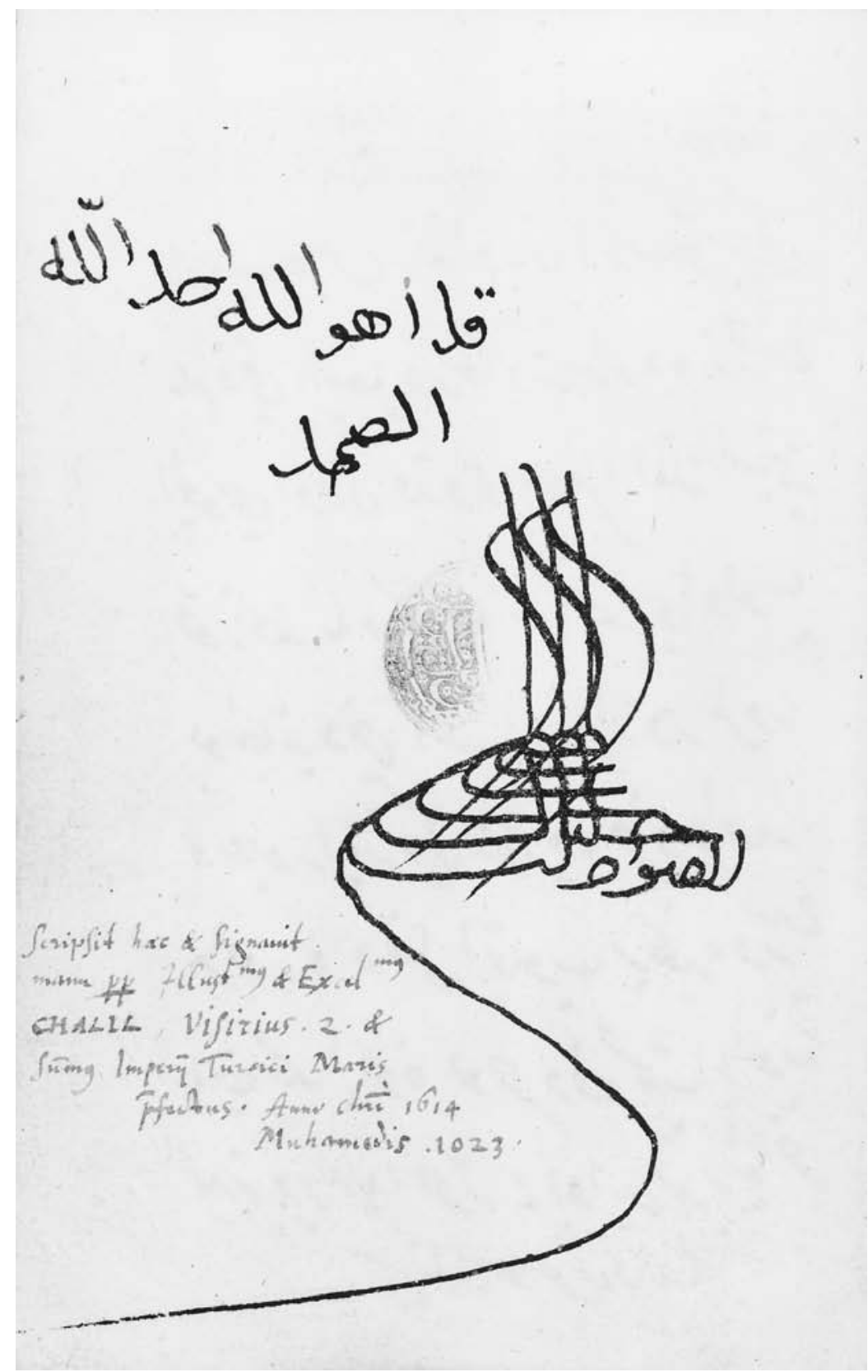

Figure 28. The Hague, KB Hs. 135 K 4, f. 11b. Signature and seal of the Ottoman Admiral, Kapudan, Halil Pasa, dated 1023/1614, found in an album amicorum compiled by Ernst Brinck, secretary to the first Dutch ambassador to the Porte. 
(1750-1835; see for his manuscripts, Leiden, UB, Academy of Arts and Sciences, below), and later to the collector of rare books and coins (and biographer of the compiler), Frans Alexander van Rappard (1793-1867); it was finally acquired by the library at an auction in Munich in 1973. The Turkish fragments are the following:

(1) ff. 10a-11b.

A copy of a letter of safe-conduct, issued by the kapudān, Halī Pasa, to Ernst Brinck, with explanations in Latin (these are printed in Van Rappard, Ernst Brinck, p. 40). It is dated Rebīü l-ähir 1023 (May-June 1614). The brief text reads as follows (10a): işbu hāamil-i rıḳ'a olan Ernesto Brinḳ-nām zimmī bi'l-fil Der-i sa 'ādet-medārda Nederland elçisi olan ḳudvetü l-ümerā l-milletü l-mesịhìye Kornelhaga-nām [Cornelis Haga] begzādenün kethüdası olub bu cānibe dahı intisābı vardur mürūr ü 'ubūr etdügi mahallerde ferd-i vāhid-i mezbūrı dahl etmeyüb rencìde vü remìde etmemek içün bu hurüf ketb olunub yedine verildi hurrire evāyil-i şehr Rebïü l-ähir sene sü̈s ve 'aşerīn ve elf. The following page (11b), contains, after a pious formula in Arabic, the signature, with three tuggs, of Halīl Paşa. See on Hualil Paşa's role as supporter of Ottoman-Dutch relations: De Groot, Ottoman Empire, pp. 106-181, passim.

\section{(2) ff. $13 b$}

A distich in calligraphic nesih against a background of gold stippling: gözlerüm ḳanlu yaşın der bu serāser cānānumdur [?]/ gül-i handeler üzere düşer sen anı șanma şebnemdür. Below the line is an inscription in Italian of And[rea] Negroni (d. 1615), ambassador of the [Habsburg] Emperor at the Porte, dated June 1613 (cf. De Groot, Ottoman Empire, pp. 306-307).

$$
\text { (3) ff. 100b-10la. }
$$

Samples of Ottoman calligaphy, with inscriptions in neshi, div $\bar{a} n \bar{\imath}$, and siy $\bar{a}-$ kat script. These were made by 'Abdullāh Çelebi in Istanbul in [10]22 (16131614), according to a colophon in the margin of f. 10ob:

$$
\text { كتبه عبد الله هلبى فى قسطنطنيه المحروسه سنه Tri the }
$$

An explanation in Latin, octo varii modi Turcicae scripturae, is found in the margin of f. 101a. 
Catalogue entry: Alba Amicorum 38.

Literature: F.A. Ridder van Rappard, Ernst Brinck (Utrecht 1868); De Groot, Ottoman Empire, pp. 307-308. 